our national position. The responsibility for achieving good relations is placed primarily on employers, though their efforts can be frustrated unless workpeople on their side are ready to understand that any increase in their own real income depends on an increase in the prosperity of the country as a whole, and that an increase in the efficiency and prosperity of their own firms or establishments is an essential contribution to that general prosperity. Employers must therefore accept a responsibility for giving their work-people full and frank information about the fortunes of the firm. Good industrial relations are built on good faith and on mutual respect between employers' and workers' organizations, and the Subcommittee recommends that employers' organizations, nationalized industries and trade unions should increase their activities and those services which will assist in the development of such relations and that their attention should be directed to professional and other associations engaged in this field with the view of encouraging or supporting such work. The leaflet summarizes certain activities, advisory services and training courses in this field and briefly describes the work of the Committee on Human Relations in Industry which has been set up by the Department of Scientific and Industrial Research and the Medical Research Council.

\section{Science in New Zealand}

THE address delivered by H.R.H. the Duke of Edinburgh before a meeting of New Zealand scientific workers in Wellington on January 13 has been published as Bulletin No. 4 of the Royal Society of New Zealand (pp. 4. Wellington: Royal Society of Now Zealand, 1954). After a tribute to the work of New Zealand men of science and to the contributions of New Zealand in scientific development, the Duke said that, although sub-division and specialization are inevitable, the interest of the individual scientific workers need not be lessened by this specialization. The day of the private adventurer in science, however, is over. Even the universities cannot meet the demands of their science faculties and are increasingly dependent on public support. Although in general the public is sympathetic and understands that this is a necessary investment, he continued, the public can only be expected to provide the funds for scientific work for national purposes such as health, agriculture, transport and defence, if it is persuaded that science for itself is a good thing, that scientific workers and their leaders are worthy and that science directly affects conditions of life and work. Those working in science have a duty to help people to understand its various branches and methods and the conditions essential for scientific work, particularly in respect of freedom of thought and investigation and communication. No country can afford to wait for the fruits of scientific research to be handed to her, and New Zealand must herself participate in the search for new knowledge. The Duke thought that the efforts of New Zealand would be best applied to problems now at hand, and that if the right conditions are created New Zealand might expect to foster centres of original scientific work of which she could be proud. In applied research, however, particularly for military purposes, he thought it would be of enormous advantage if the countries of the British Commonwealth could pool their resources. There are not enough workers in any one country of the Commonwealth to provide all the up-to-date equipment necessary to ensure that each unit is properly prepared for a possible war, and he welcomed the creation of the New Zealand Defence Science Corps.

\section{World Population and Resources}

Prof. E. P. Stebring, Romden Castle, Smarden, Kent, in a letter to the Editors, directs attention to what appears to be a serious omission in the PEP broadsheet with this title (see Nature, July 3, p. 1) and in the report of the symposium given by members of the executive of the International Geographical Union (Nature, June 26, p. 1218). He suggests that the conservation of water supplies is an even more pressing problem than those of finding food, materials, fuel and power for the rapidly increasing world population listed as the most urgent by PEP. In most parts of the world the maintenanee of forests over catchment areas to secure an even flow of rivers and to prevent soil erosion and flooding is vital, though financially unproductive in a direct sense. Doubtless the authors of the PEP broadsheet would readily agree that water is the most vital of 'raw materials'; and the Intermational Geographical Union has established a Commission on Arid Lands to study the problem, and its president, Prof. L. D. Stamp, has repeatedly urged that the control of water is the foundation of progress in the underdeveloped lands, notably Africa. The Food and Agriculture Organization has set up a Permanent European Working Party on the Conservation of Land and Water Resources and has asked all member countries to survey their areas. Unfortunately, no response has been received from the British Government, which indeed has suspended the work of the Inland Water Survey as an economy measure.

\section{J. A. von Segner (1704-77)}

A PAYSICIAN who made distinguished contributions to physics and mathematics, Johann Andreas von Segner was born in Pressburg (Bratislava), Czechoslovakia, two hundred and fifty years ago, on October 9, 1704. After studying philosophy at Debrecen, where the Cartesian teachings were still followed, he graduated M.D. at the University of Jena in 1730 . Attending the lectures of Georg Erhard Hamberger, professor of medicine, he acquired his lifelong interest in mathematics. In 1733 he was appointed associate professor of philosophy at Jena, and two years later professor of physics and mathematics at the newly founded University of Göttingen, where after the death of J. W. Albrecht in 1736 he was for a time the only professor in the medical faculty. In 1755 he accepted the corresponding chair at Halle. An indefatigable worker and a voluminous writer of dissertations on physics, chemistry, mathematics, geometry and medicine, he introduced a naval barometer in 1743 , and in 1750 constructed a waterwheel which bears his name. While he made no original discoveries in medicine, he refuted the theories of the iatromathematical school, establishing mathematics as a handmaiden of medicine. His acquaintance with the principles of Christian Wolf led him to abandon the Cartesian philosophy. Segner's scientific merits were recognized by his contemporaries, for he was created a privy counsellor and wais granted letters of nobility by the king of Prussia. He died on October 5, 1777, at the age of seventy-three.

\section{Steroid Reference Collection}

THE Clinical Endocrinology Committee of the Medical Research Council has been concerned for 